\title{
Investment Arbitration and the Public Interest
}

\author{
Gábor Hajdu*
}

\begin{abstract}
The study focuses on analyzing conflicts between (international) investment arbitration and the public interest, dividing its contents into five substantive sections. First, it summarizes the common characteristics of international investment arbitration (distinguishing procedural and substantive elements), followed by its most pressing issues (including frequent criticism such as lack of consistency, asymmetrical proceedings, regulatory chill, etc.). Afterwards, selected investment arbitration cases are examined, grouped based on which areas of public interest they affected (environmental protection, employee rights, public health). These cases all hold relevance and offer different insights into the workings of investment arbitration, which serve to illuminate the complex interplay between foreign investor and public interest. The cases also provide the foundation for the study's conclusions, where key observations are made on the central subjects.
\end{abstract}

Keywords: BIT, ILA, ISDS, unclean hands, regulatory chill.

\section{Introduction}

International investment arbitration does not look back on a long history; however, its prevalence is undeniable. We can identify several details that serve as the source of this popularity, all of which contributed to the rise of investment arbitration in their own way.

Firstly, we can point to the general economic developments in the post-World War II era. With the exception of socialist countries, a general tendency towards increased economic globalization slowly emerged. First in relation to trade, but eventually, investors from wealthy countries began to look for opportunities to invest their capital into developing countries, be that for the reason of untapped natural resources, cheaper workforce or more lenient regulations. Thus, from the foreign investors' perspective, there was a drive towards using their capital abroad, and foreign investments started to proliferate all over the globe. ${ }^{1}$

Secondly, again from the foreign investors' perspective, was the general atmosphere of uncertainty surrounding the governments of newly decolonized developing countries and the unreliability of their domestic court systems in the

* Gábor Hajdu: PhD student, University of Szeged.

1 See Klaus E. Meyer, 'Foreign Direct Investment in Emerging Economies,' Emerging Markets Forum, 2015; Kenneth J. Vandevelde, 'A Brief History of International Investment Agreements', U.C. Davis Journal of International Law \& Policy, Vol. 12, 2005, pp. 157-194. 
1950s and 1960s. To the foreign investors, stability and legal reliability are both paramount, so it is sensible that they would seek alternate means of ensuring that their investments are safe and protected from nationalization, expropriation or other discriminatory or restrictive governmental measures. While there was a demand to export capital as explained in the above paragraph, this specific circumstance seemed to be an obstacle. ${ }^{2}$

Furthermore, from the perspective of the host countries, it had become increasingly clear that they could not rely on their own internal reserves of capital to develop their economy. Thus, attracting foreign capital became an absolute necessity for ensuring economic development, creating jobs, finding new markets, and benefiting from technology transfer. ${ }^{3}$ This naturally incentivized potential host countries to find a solution and provide adequate safeguards to foreign investors.

Thus, we can conclude that there was a meeting of minds, or perhaps interests between foreign investors (represented by their own governments) and the host countries' governments. These elements together paved the way for a solution: the emergence of the investment arbitration system. With the rapid expansion of Bilateral Investment Treaties (BITs) in the past half a century, especially in the 1990 s, ${ }^{4}$ this system gradually took shape and has become greatly preferred by foreign investors. ${ }^{5}$ With additions such as the International Centre for the Settlement of Investment Disputes (ICSID), investment arbitration seemingly secured its strong position as the investment dispute resolution system. ${ }^{6}$

However, this position is continuously assailed by criticism. Especially in the last ten years, criticism towards the investment arbitration system has been mounting incessantly, citing various perceived problems and the apparent conflict between public interest and foreign investors. ${ }^{7}$ Regardless, investment arbitration has so far remained a staple of international agreements on the treatment of foreign investors, with only one notable exception (CETA). ${ }^{8}$

In this article, we will first identify the unique characteristics of investment arbitration and the key criticisms that are relevant to the subject at hand, followed by a discourse on the interplay between public interest and investor

2 Vandevelde 2005, pp. 161-167.

3 Zoltán Víg, 'The Importance of Foreign Direct Investments and Instruments for their Protection', Hungarian Journal of Legal Studies, Vol. 59, Issue 4, 2018, p. 443.

4 Suzanne Kirayoglu, The Bilateral Investment Treaty: Its Origins and Effects, Florida State University, 2014, p. 22.

5 Hasrat Arjjumend, 'Regulatory Chill, Corporate Takeover and Environmental Governance', International Journal of Current Advanced Research, Vol. 6, Issue 12, 2017, p. 7924.

6 See e.g. Antonio R. Parra, The History of ICSID, Oxford University Press, Oxford, 2012.

7 Caio Cesar Soares, 'Investor-State Dispute Settlement: An Analysis of the Reform Proposals on Its Institutional Structure', SSRN, 2017, pp. 2-3, at https://ssrn.com/abstract=2984581.

8 Shilpa Singh, 'Analyzing Features of Investment Court System under CETA and EUVIPA: Discussing Improvement in the System and Clarity to Clauses', Kluwer Arbitration Blog, 2019, at http://arbitrationblog.kluwerarbitration.com/2019/02/08/analyzing-features-of-investmentcourt-system-under-ceta-and-euvipa-discussing-improvement-in-the-system-and-clarity-toclauses/. 
interest. This will be supported by the examination of several notable investment arbitration cases. And finally, a conclusion will be drawn from all that was discussed, aiming to determine a few key observations, and what the future will hold for investment arbitration and its potential conflict with public interest.

\section{Characteristics and Criticisms of Investment Arbitration}

When identifying the unique characteristics of investment arbitration, it seems prudent for us to establish two general categories: characteristics related to procedural rules (such as the initiation of the dispute resolution, the formation and constitution of the arbitration tribunal, etc.), and characteristics related to the substantive law utilized by arbitral tribunals. While these two general categories have connecting points with each other, and they are partially entwined, examining them separately will allow us to present a clearer picture of the overall system. The study will also present related criticisms alongside the characteristics, as appropriate.

The first preliminary issue that should be established regarding procedural rules is that there are several different possible arbitral frameworks that a given investment dispute could use. This is determined by the treaty (or by the parties' agreement) that provides the basis for the investment arbitration process in the given case. Typically, BITs leave room for the parties to select a procedural framework. However, the most widespread and popular rulesets are the ICSID and the UNCITRAL Arbitration Rules. ${ }^{9}$

The most important common procedural characteristic of the investment arbitration system is, that unlike diplomatic methods of dispute resolution, the two parties in the investment arbitration are always the foreign investor and the host state. Although BITs are signed by states, the foreign investor's state plays only an indirect role in the arbitration proceedings, the foreign investor itself will be the primary representative of its own interests. Furthermore, domestic investors are naturally excluded from international investment arbitration due to the lack of a foreign element. When determining the 'nationality' of a foreign investor, investment arbitrators typically look for the ultimate controlling interest, thus allowing domestic companies to participate as complainants, provided they are subsidiaries of a foreign company or are otherwise under the control of foreign investors. ${ }^{10}$

Not only is the nature of the parties involved always set, their exact position in the dispute are also fixed. The complainant will always be the foreign investor, while the respondent will always be the host state. This means that host states have no ability to initiate disputes under the aegis of the investment arbitration system. Their ability to present counterclaims is also significantly limited by most BITs. Thus, the foreign investor will have almost exclusive control over whether

9 See at https://icsid.worldbank.org/en/Pages/icsiddocs/ICSID-Convention-Arbitration-Rules.as px; see also at https://uncitral.un.org/en/texts/arbitration/contractualtexts/arbitration.

10 David Gaukrodger, 'Investment Treaties and Shareholder Claims: Analysis of Treaty Practice', OECD Working Papers on International Investment, 2014/03, pp. 27-29. 
the investment arbitration will be initiated at all, and what claims will be presented before the arbitration tribunal. ${ }^{11}$

The one-sidedness of investment arbitration initiation is often considered rather problematic, as it creates an inherent power balance discrepancy between foreign investors and host states. This naturally occurs, because whenever there is a dispute between the foreign investor and the host state, only the foreign investor may turn to investment arbitration and initiate proceedings. Combined with the limited ability to present counterclaims on the host state's side, this could easily be considered a great advantage to the foreign investor. ${ }^{12}$ Obviously, foreign investors do have a certain advantage with regards to initiating investment arbitration proceedings, but we also have to keep in mind that investment arbitration itself is essentially a compensatory dispute resolution mechanism, designed precisely to provide foreign investors with the option to protect their investments when the host state's domestic courts and processes are potentially unreliable. It should not be forgotten that as sovereign entities, host states already have the ability to enforce their will on the foreign investor (with regards to their investments and other assets in the host state). Therefore, we could easily argue that this one-sidedness does not really create a power imbalance, but in fact alleviates an inherent power discrepancy between the foreign investor and the host state due to their contrasting nature as a private actor versus state entity.

A related issue that is sometimes raised as well is the fact that domestic investors have no access to international investment arbitration. Given that investments made by domestic and foreign investors might be competing with each other, recourse to investment arbitration in case of a dispute with the given government could be construed as an unfair advantage. If a given governmental measure inflicts harm to both foreign-made and domestic-made investments, only the foreign investor will be able to seek international investment arbitration to redress their grievances. By contrast, the domestic investor will be at the mercy of the domestic court system and legal processes in this situation. ${ }^{13}$ However, it is worth noting that as presented earlier in the study, the very essence of international investment arbitration rests in its nature as a solution to disputes between foreign investors and host states. Domestic investors do not fit into the overall concept of this system, and their inclusion would be unfounded, as BITs and general free-trade agreements with investment chapters naturally focus on granting these rights to each other's investors, not to their own investors who

11 Soares 2017, p. 11.

12 Gus Van Harten, 'Investment Treaty Arbitration, Procedural Fairness, and the Rule of Law', in Stephan Schill (ed.), International Investment Law and Comparative Public Law, Oxford University Press, Oxford, 2010, p. 4.

13 See e.g. Ingolf Pernice, 'Study on International Investment Protection Agreements and EU Law', in Directorate-General for External Policies of the Union Policy Department (ed.), Investor-State Dispute Settlement (ISDS) Provisions in the EU's International Investment Agreements, p. 132; Gus Van Harten, 'Is It Time to Redesign or Terminate Investor-State Arbitration?', Centre for International Governance Innovation, 2017, at www.cigionline.org/articles/it-time-redesign-orterminate-investor-state-arbitration. 
can be handled through domestic legislation. In a similar fashion, justification for investment arbitration rests on the notion that the host state's domestic courts and proceedings are inherently less amenable to foreign investors. Conversely, this could be understood as meaning that they can be more favorable to domestic investors than foreign ones, thus, the foreign investors' access to investment arbitration is compensated by the domestic investor having better access to domestic methods of dispute resolution and being better able to pursue its rights within the country, as opposed to the foreign investor. The domestic investor can also, in theory, simply agree to a form of arbitration with its own state.

When it comes to the formation and constitution of the arbitration tribunals, investment arbitration typically follows a rather classic method. While it depends on the exact BIT and the procedural ruleset at play, there are usually three arbitrators, two chosen by each of the parties, with the third being chosen by the parties together. If they cannot reach common ground on that, the ICSID Convention Arbitration Rules offer the option of having the Chairman of the (ICSID) Administrative Council appoint the missing arbitrator at the written request of either party. ${ }^{14}$ As for the arbitrators themselves, they are usually renowned international legal experts, who operate in a for-profit format, receiving financial compensation by the parties for their role in the arbitration tribunals.

In general, the formation and constitution of arbitration tribunals encounter less criticism, but it is notable that as mentioned beforehand, arbitrators operate on a for-profit basis. Combined with the fact that only foreign investors can initiate investment arbitration proceedings, it has led to the notion that arbitrators might be more inclined towards foreign investors in their decisions. ${ }^{15}$ Furthermore, some critics have posited that the perceived institutional bias of arbitrators is concerning enough in itself. ${ }^{16}$ However, this general line of thought can be countered by two arguments. First, statistics do not support the assertion that investment arbitrators are more favorable to investors, as this would mean that the majority of the cases are won by the foreign investors, which is not factual. ${ }^{17}$ Second, while the existence of a given tribunal is dependent solely on the foreign investor, in its constitution the host state has equal say.

Another potential line of criticism is geared towards the duties of assistants working with the arbitrators, especially with regards to how far they can go in their duties when it comes to assembling the arbitration tribunal's reasoning. The

142006 ICSID Convention Arbitration Rules, Chapter 1, Rule 4.

15 Cecilia Olivet \& Pia Eberhardt, 'Profiting From Injustice: How Law Firms, Arbitrators and Financiers Are Fuelling an Investment Arbitration Boom', Transnational Institute, 2012, at www.tni.org/en/briefing/profiting-injustice.

16 See e.g. Gus Van Harten, 'Fairness and Independence in Investment Arbitration: A Critique of Susan Franck's “Development and Outcomes of Investment Treaty Arbitration”, SSRN, 2011, at https://ssrn.com/abstract=1740031.

17 See e.g. Howard Mann, 'ISDS: Who Wins More, Investors or States?', Investment Treaty News, 2015, at www.iisd.org/itn/wp-content/uploads/2015/06/itn-breaking-news-june-2015-isdswho-wins-more-investors-or-state.pdf. 
famous Yukos case is a good example for this dilemma, where such an assistant's participation in writing the award was the subject of dispute. ${ }^{18}$

The final procedural characteristic that should be noted is that the 'loser pays' principle is not applicable in investment arbitration. This is a near-universal principle of this dispute resolution system, regardless of the BIT or procedural framework that serve as the proceedings' backdrop. Each party must independently bear their legal expenses. The expenses incurred by the arbitrators and their staff are similarly divided between the parties. Furthermore, the tribunal may only assign an award to the foreign investor, so the host state always faces a net financial deficit regardless of the proceedings' ultimate outcome. ${ }^{19}$

The cost of proceedings is thus a major criticism of the system. Legal fees associated with investment arbitration are steep, as both sides have to finance specialized teams of international lawyers and also compensate the arbitrators and their staff. And due to the lack of the 'loser pays' principle, even if the host state emerges as the ultimate winner, they still technically end up with a net loss financially due to the cost of the proceedings as previously noted. Furthermore, investment arbitration awards for the benefit of foreign investors can also pose a significant financial problem, especially if the host state in question is a developing nation. ${ }^{20}$

We can also establish some common characteristics regarding the substantive aspects of investment arbitration. In a similar fashion to the procedural characteristics, we must first mention that the primary (and near-exclusive) legal basis for investment arbitration and its rulings are the BITs and more recently, the investment chapters of free-trade agreements. ${ }^{21}$ Arbitration tribunals do not interpret domestic law on their own, only to the extent whether said piece of legislation is legitimate considering the provisions of the given BIT or FTA. ${ }^{22}$

Despite the large number of these BITs, most have similar substantive provisions. ${ }^{23}$ First of these are the definitions. BITs always contain a number of definitions ranging from common terms such as investor, investment, and so on. For investment arbitration tribunals, it is very often necessary to interpret these definitions. The bases for such interpretations vary greatly, however. Compared to say domestic legislation, BITs lack a definite reading supplied by the domestic

18 Dmytro Galagan, 'The Challenge of the Yukos Award: An Award Written by Someone Else - A Violation of the Tribunal's Mandate?', Kluwer Arbitration Blog, 2015, at http:// arbitrationblog.kluwerarbitration.com/2015/02/27/the-challenge-of-the-yukos-award-anaward-written-by-someone-else-a-violation-of-the-tribunals-mandate/.

19 See e.g. Matthew Hodgson \& Alastair Campbell, 'Damages and Costs in Investment Treaty Arbitration Revisited', Global Arbitration Review, 2017, at www.allenovery.com/en-gb/global/ news-and-insights/news/damages-and-costs-in-investment-treaty-arbitration-revisited.

20 Lise Johnson \& Lisa Sachs, 'The Outsized Costs of Investor-State Dispute Settlement', Academy of International Business Insights, Vol. 16, Issue 1, 2016, p. 11.

21 Vandevelde 2005, pp. 184-193.

22 Lise Johnson et al., 'Investor-State Dispute Settlement, Public Interest and U.S. Domestic Law', CCSI Policy Paper, 2015, p. 2, at http://ccsi.columbia.edu/files/2015/05/Investor-State-DisputeSettlement-Public-Interest-and-U.S.-Domestic-Law-FINAL-May-19-8.pdf. 
court system, the local legal culture or precedents. As such, these definitions often have to be interpreted on their own, though arbitrators might draw from previous similar investment cases or international legal literature on the subject. Regardless, this is not mandatory for them. ${ }^{24}$

Standards of treatment can be considered another critical characteristic of substantive rules when we are discussing investment arbitration. These typically range from familiar phrases such as national treatment and most-favored nation (MFN) treatment to the ubiquitous 'fair and equitable treatment' (FET) standard. ${ }^{25}$ In a similar fashion to definitions, investment arbitration tribunals are free to interpret these standards and their applicability to the given dispute. There is no uniform interpretation of these standards, and hence arbitrators are free to rely on their own judgment and may use any particular source for rendering their decisions. ${ }^{26}$

As for the key criticisms related to the substantive elements of investment arbitration, it all comes down to the issue that there is no authoritative body to provide a uniform legal interpretation of these treaties, and that precedents do not have to be followed. As noted beforehand, investment arbitrators decide cases based on their own readings of the given definitions and standards of treatment within the treaties. This could be interpreted as posing the issue of legal uncertainty regarding the outcome of the cases, as the parties may never be exactly sure how the arbitration tribunal would interpret a given passage of the BIT or other treaties. ${ }^{27}$

\section{The Issue of Public Interest}

All of the previous criticisms of the investment arbitral system lead to our main subject at hand: public interest. Within the context of international investment law, a public interest regulation is any kind of regulation that has a basis different than a state of necessity, public order or national security. ${ }^{28}$ This naturally means that they cover a wide range of subjects, though their importance is not diminished by this diversity. In particular, fields such as labor law, environmental law and public health regulation can all be considered to be of great relevance to a given state's legislative function.

However, the interests of foreign investors are very frequently at odds with the public interest of the given host state. From the foreign investor's perspective, what is beneficial is a lax system of regulations that allows them to maximize the profits of their investments. However, the public interest often demands stricter regulation. This is especially the case in the aforementioned

24 Soares 2017, pp. 24-27.

25 See e.g. UNCTAD, 'Fair and Equitable Treatment', UNCTAD Series on Issues in International Investment Agreements II, 2012.

26 Soares 2017, pp. 24-27.

27 Id.

28 Alison Giest, 'Interpreting Public Interest Provisions in International Investment Treaties', Chicago Journal of International Law, Vol. 18, Issue 1, 2017, p. 334. 
fields, such as labor law or environmental law. E.g. foreign investors want the lowest possible minimum wage in order to increase their returns on their investment. ${ }^{29}$ In a similar fashion, environmental regulation is usually harmful to the foreign investors, forcing them to reduce their profit in order to comply with the regulations. Health regulations can also lead to a loss of profit. Because of these reasons, most BITs and other investment-related treaties contain provisions that affirm the right of the host states to legislate in pursuit of legitimate public interest. ${ }^{30}$ This appears to be an easy solution to this apparent conflict.

However, in reality, the issue is not so simple. First, we have to consider that these provisions are often vaguely defined, giving significant leeway to investment arbitrators when it comes to interpreting them. Especially terms such as 'legitimate' could pose a challenge. This is compounded by the burden of proof: from the foreign investor's side, it is often only necessary to prove that damages were incurred and that these damages were in direct connection with or the result of a government measure. Thus, it is frequently the host state's obligation to prove that said measure fell within legitimate public interest, and that no provision was violated. ${ }^{31}$

Secondly, there might be an internal conflict of interest within the host state itself. While there could be a sort of public interest that the state intends to pursue, such as environmental or social goals, it is also true that they can have an economic and a budgetary interest as well. Introducing measures that 'ruffle the feathers' of foreign investors could lead to the pulling out of the said investors and perhaps even others from the given host state. And as it was noted in the introduction, the host states are often reliant on foreign capital for economic development. Hence, deciding to pursue a public interest-based policy could easily lead to an economic downturn, which might not be something the host state's government is willing to risk. There is also a more direct concern regarding the costs of investment arbitration, particularly when the foreign investor ends up winning the case and is awarded damages. These sums could easily end up amounting to a significant percentage of the host state's budget, especially when it comes to a developing country with a weaker economy and financial reserves. ${ }^{32}$ Not respecting the ruling carries its own set of dire consequences, and could easily lead to capital flight and cause a recession due to shortage of foreign capital. ${ }^{33}$

29 E.g. Veolia Propreté v. Arab Republic of Egypt, ICSID Case No. ARB/12/15, at https:// investmentpolicy.unctad.org/investment-dispute-settlement/cases/458/veolia-v-egypt.

30 See e.g. Vera Kozun, 'The Right to Regulate in Investor-State Arbitration: Slicing and Dicing Regulatory Carve-Outs', Vanderbilt Journal of Transnational Law, Vol. 50, Issue 2, 2017, pp. 355-414.

31 Angelos Dimopoulos, 'Climate Change and Investor-State Dispute Settlement: Identifying the Linkages', in Panagiotis Delimatsis (ed.), Research Handbook on Climate Change and Trade Law, Edward Elgar, Cheltenham, 2016, p. 430.

32 Hodgson \& Campbell 2017.

33 Ashley Schram et al., 'Internalisation of International Investment Agreements in Public Policymaking: Developing a Conceptual Framework of Regulatory Chill', Global Policy, Vol. 9, Issue 2, 2018, p. 3. 
Under such circumstances and given the above issues related to investment arbitration, it may be economically advantageous for the host state's government to simply not implement their own measures and let foreign investors have their way, rather than risk a protracted investment arbitration proceeding. In general, we call this phenomenon regulatory chill. Its existence is controversial and difficult to prove (as insight into the minds of legislators and executives is rare and hard to obtain). Furthermore, different scholars posited different types of regulatory chill. ${ }^{34}$ The concept could be categorized in a number of different ways, such as anticipatory chill, which is the version we described above, or direct chill where there is a concrete threat of investment arbitration from foreign investors. Some have also posited the existence of a precedential or cross-border chill, where concluded (or even ongoing) investment arbitration cases affecting a nearby state, could influence a given host-state in its decision-making, in case it is also considering similar measures. ${ }^{35}$

Thus, the next logical step is to examine a few relevant cases of investment arbitration, where we can observe the discussed clash between public and investor interests. These will be organized into three categories based on the public interest element: instances where investor interest clashed with environmental protection, instances where investor interest clashed with employee rights, and instances where investor interest clashed with public health concerns. Using these examples, it will be possible to make a few observations, and draw a conclusion from these regarding the future.

\section{Foreign Investors Versus Environmental Protection}

In this particular section, three cases won by foreign investors will be presented, each aimed at showing how environment-related public interest can be trumped by foreign investor interest, and how having 'unclean hands' is often not an obstacle for foreign investors in getting their way.

Occidental Petroleum v. Ecuador ${ }^{36}$ stands out as an infamous investment arbitration case with one of the largest investor awards in the history of the system. This particular dispute concerned the US-based oil corporation known as the Occidental Petroleum Corporation and the government of Ecuador. Their dispute was based around the termination of a certain oil license in the Amazon region, originally granted to the corporation by the Ecuadorian government. This license was embodied by a contract between the corporation and the government. The contract mandated that the sale of production rights without pre-approval by

34 See e.g. Satwik Shekhar,"Regulatory Chill': Taking Right to Regulate for a Spin', Centre for WTO Studies, WP/200/27, 2016; Kyla Tienhaara, 'Regulatory Chill and the Threat of Arbitration: A View from Political Science', in Chester Brown \& Kate Miles (eds.), Evolution in Investment Treaty Law and Arbitration, 2011.

35 Kyla Tienhaara, 'Regulatory Chill in a Warming World: The Threat to Climate Policy Posed by Investor-State Dispute Settlement', Transnational Environmental Law, Vol. 7, Issue 2, 2018, pp. 229-250.

36 Occidental Petroleum Corporation and Occidental Exploration and Production Company v. The Republic of Ecuador, ICSID Case No. ARB/06/11, at www.italaw.com/cases/767. 
the Ecuadorian government would constitute a breach of the contract, as Ecuador's hydrocarbons law provisioned the thorough appraisal of companies seeking to extract resources in the environmentally fragile Amazonas area. Said law was also explicitly integrated into the contract.

However, in 2006, the corporation decided to sell off $40 \%$ of its production rights without first requesting the approval of the Ecuadorian government, which led to Ecuador claiming a breach of the contract (as well as a violation of the above-mentioned law) and ultimately, the termination of the entire oil license. In turn, the corporation initiated investment arbitration against Ecuador, based on the Ecuador-US BIT. In particular, it claimed that Ecuador's contract terms and the law in question violated the 'fair and equitable treatment' standard.

Interestingly, the tribunal in this particular case used a proportionality argument: it stated that while the corporation did indeed act unlawfully and the government's response was justified, it still noted that the 'fair and equitable treatment' standard demanded an implicit degree of proportionality and that Ecuador's actions were not proportionate to the breach of contract the US corporation committed. As such, the tribunal found Ecuador to be in the wrong, and awarded nearly 1.8 billion USD to Occidental. This enormous sum was calculated based on the future profits of the corporation if it had the chance to exploit fully the oil reserves contained within the license. More bizarrely, the tribunal chose to disregard that Occidental attempted to sell $40 \%$ of its production rights, and instead used the full license as the basis of the calculation. In a very small victory for the host state, it did determine that the corporation was responsible for $25 \%$ of its projected losses due to the aforementioned breach of contract, but for the rest, Ecuador was liable.

Ecuador later attempted to annul the award, which only partially succeeded in 2015. The annulment committee did decide that the above noted $40 \%$ of the production rights should be excluded from the calculation of damages, and thus reduced the award to 1 billion USD.

Occidental Petroleum v. Ecuador is a strong example of the seemingly outlandish interpretations investment tribunals can sometimes use. The 'fair and equitable treatment' standard did not necessarily mandate a degree of proportionality, yet the tribunal chose to interpret it in such a way. Furthermore, this case highlights a certain tendency in investment arbitration cases to (at least partially) disregard the 'unclean hands' of foreign investors (that is to say, the foreign investor acting in bad faith or even operating in a criminal manner in the host state), even if the host state was pursuing a legitimate public interest with its measures. This tendency will also be reflected by the following Copper Mesa case.

Copper Mesa v. Ecuador was another case that affected Ecuador as the host state. $^{37}$ This particular dispute also concerned a resource license, this time a mining license. The background of the case goes back to the late 1990s when large ore deposits of copper were discovered in the Ecuadorian Northwest. The related 
license was initially granted to a national, but it was later sold to a Canadian mining company (through its subsidiaries). Afterwards, the foreign investor began developing the area. This was met by organized resistance from the local communities, who were concerned about the environmental effects of Copper Mesa's mining activities. According to allegations by Ecuador, Copper Mesa responded in a rather heavy-handed and legally questionable manner to these protests. In the end, it was this conflict with the locals that prompted Ecuador to terminate the license through a new legislation called the Mining Mandate (2008), which allowed the expropriation of certain mining licenses without economic compensation. This ultimately occurred to Copper Mesa's licenses as well.

Whereupon, Copper Mesa initiated investment arbitration under the CanadaEcuador FIPA. Regarding jurisdiction, there was a dispute between the parties about whether Copper Mesa is allowed to advance damage claims for damages that were directly suffered by its subsidiaries, who therefore must each consent to arbitration separately. The tribunal sided with the company on the matter, arguing that Copper Mesa was only advancing a claim for the damages that it itself suffered as an investor. The second interesting element is related to the issue of 'unclean hands.' Ecuador tried to argue, based on a considerable body of evidence, that due to the illegal actions of Copper Mesa, there should be no jurisdiction, heavily relying on international legal doctrines in the process. This was rebuffed by the tribunal as a question of admissibility, not jurisdiction, and that Ecuador failed to raise these international legal points before the arbitration's commencement. Thirdly, the tribunal concluded that Ecuador acted in an arbitrary manner and neglected due process. Finally, while the tribunal ultimately found in favor of Copper Mesa, it did end up noting that the corporation contributed $30 \%$ of its loss through contributory negligence, ending in an approximately 20 million USD award in total (and compound interest).

This case is a particularly extreme example of the 'unclean hands' doctrine being ignored by arbitration tribunals. Furthermore, despite the circumstances presented in the case, the tribunal did not acknowledge the legitimacy of the Ecuadorian public interest, as the government was ultimately acting on the request of local communities adversely affected by the mining activities of Copper Mesa. Perhaps it is partially for this reason that the enforcement of the award is still pending, as Ecuador managed to successfully delay its payments. ${ }^{38}$

Another relevant case related to foreign investor interests clashing with environmental protection, though of less financial significance compared to Occidental Petroleum, is Abengoa v. Mexico. ${ }^{39}$ This case is particularly notable for the fact that unlike in the previous two examples, the central, or rather federal, government, was supportive of the foreign investor in its activities, with the source of conflict arising solely from the side of municipality. In this particular www.law360.com/articles/898360/defunct-canadian-miner-says-ecuador-avoiding-24m-award.

39 Abengoa S.A. y COFIDES S.A. v. United Mexican States, ICSID Case No. ARB(AF)/09/2, at www.italaw.com/cases/1871. 
case, a Spanish corporation planned to construct a waste management plant. Not long after the construction began, the corporation's efforts to construct the plant met with local opposition, which included the creation of a new civil association called 'Unidos por Zimapán' that mounted a campaign against the plant's construction for environmental reasons. Another group was later formed by the civil association, specifically aimed at impeding the plant's installation. The local authorities eventually started siding with protesters, and refused to renew the company's construction license at the end of 2007. Regardless, the foreign investor continued to construct the plant, and even used the Mexican federal police to protect its interests against the civilian protest groups as violence escalated, which led to the company's operating license being completely revoked by 2010. This decision by the municipality was opposed by federal authorities. After the plant's completion, the municipal authorities refused to allow the plant's operation, citing that its license was invalid, and the above-mentioned public interest concerns still stood. This led to the foreign investor initiating arbitration against Mexico under the Spain-Mexico BIT.

The arbitration tribunal ultimately found in favor of the Spanish investor, noting that the municipality's actions in denying and impeding licenses for the waste plant amounted to indirect expropriation and violated the 'minimum standard of treatment' principle. As a consequence, it awarded more than 40 million USD to the foreign investor in damages.

While the above three were only a selection of the most infamous cases related to environmental interests, they still sufficiently display the potential consequences of investment arbitration. Arbitration tribunals can have different priorities and views compared to public interests in host states. It is often the case that, even though a black letter reading of investment treaty provisions may lead to certain outcomes, doing so also ends up harming potentially legitimate public interest, especially when it comes to environmental concerns. And as investment treaties are often vaguely worded and offer significant room for interpretation (as we have seen e.g. in how the tribunal in Occidental Petroleum expanded 'fair and equitable treatment' to contain reciprocity, or how the notion of the foreign investors breaking domestic laws and pursuing illegal courses of action was so easily dismissed as irrelevant by the tribunal in Copper Mesa), strange and unexpected outcomes can easily come about.

\section{Foreign Investors Versus Employee Rights}

While there are other investment arbitration cases related to labor law, Veolia $v$. Egypt $^{40}$ is the most relevant from the study's perspective, as it serves to demonstrate investment arbitration's potential for seemingly frivolous investor claims that are accompanied by costly proceedings. Unlike the other cases included in this study, Veolia was not made public, but secondary sources are 
available to supplement the official information, which can be used to examine the key details of the case. ${ }^{41}$

The basis for the dispute lies in a contract between the Alexandrian municipal government and Veolia, a French corporation. This contract centered around Veolia providing waste management services in Alexandria over a fifteen-year period. However, when Egypt revised some of its labor laws, leading notably to an increase in minimum wage, the foreign investor initiated investment arbitration proceedings against the country, claiming that they suffered a loss in relation to their investment. The basis of these proceedings was the France-Egypt BIT.

Based on the information available, the proceedings lasted for six years in total (three years spent on jurisdictional matters and three years on the merits of the case), and ultimately ended with Egypt's victory and the investor's claims being rejected. However, it can be argued that this was not a true victory for the country, as it still had to endure six years of arbitration and the associated legal and arbitrator fees. This is especially egregious when considering the nature of the dispute, and that something that is usually taken as the sovereign right of every state (raising the minimum wage) would be considered grounds for investment arbitration. Of course, one can raise the obvious counter-argument that if there was a guarantee of a certain degree of profit in the original contract, or if the contract ensured that certain legitimate expectations were to be met, then there was a responsibility for Egypt to respect that. Obviously, this issue is further muddled by the fact that the contract was concluded by a municipal government, which had no control over the actions of the Egyptian national government and legislature. In conclusion, this case highlights the difficulty in determining where legitimate investor expectations end, and where commonsense state sovereignty begins.

The second case to be discussed here is AbitibiBowater v. Canada. ${ }^{42}$ This particular case occurred between a US investor and Canada. The basis was that the US corporation owned several timber mills and hydroelectric plants within a province of Canada. As a result of the 2008 financial crisis, the corporation began closing these mills, causing many of its employees to lose their jobs. In response, the provincial legislature ended the corporation's local forestry and water rights, and expropriated its related, still extant, assets. Compensation was determined to be subject at the discretion of the provincial government itself. These decisions were allegedly made so as to mitigate the consequences of the corporation's restructuring and preserve the jobs still available in the province.

As a direct consequence of the legislature's decision, the corporation initiated investment arbitration against Canada, based on Chapter 11 of the NAFTA, under UNCITRAL rules, seeking 500 million Canadian dollars in damages. However, this case notably closed before it could begin, as AbitibiBowater successfully

41 See e.g. https://isds.bilaterals.org/?veolia-loses-isds-case-against\&lang=en; www.bilaterals.org/? french-company-veolia-launches\&lang=en;www.iisd.org/itn/2015/02/17/political-change-vslegal-stability-problems-arising-from-the-application-of-investment-treaties-in-transitionsfrom-authoritarian-rule/.

42 AbitibiBowater Inc., v. Government of Canada, ICSID Case No. UNCT/10/1, at www.italaw.com/ cases/39. 
negotiated a settlement with the Canadian government, leading to a 130 million Canadian dollars payout to the foreign investor.

With regards to this particular case, it could be argued that the foreign investor was merely acting to preserve its own finances, hence the closures of its facilities in the province. On the other hand, there was also a legitimate public interest on the side of the provincial government, in seeking to preserve the continued operation of these facilities, that were likely vitally important to the continued wellbeing of local communities (through providing employment). And while the case never went to arbitration, the foreign investor still triumphed and the host state still lost in a sense, as 130 million Canadian dollars were paid to the investor as part of the settlement. Furthermore, it must be noted that this occurred against the backdrop of an economic crisis and the recovery period after it. Under such circumstances, both foreign investors and host states may jump to taking rash actions and measures, but only host states (and their taxpayers) will be 'punished' later for these.

\section{Foreign Investors Versus Public Health}

The first case to be discussed here is similar to the previous Canadian case in some respects but is at the same time a much older case. This, however, does not diminish its continued relevance and importance, and as such, serves as an excellent example of what long-term effects investment arbitration can cause. Ethyl v. Canada ${ }^{43}$ concerned a dispute between a US chemical company and Canada, and was based on MMT, a certain gasoline additive that was often used to improve the performance of engines. Canada decided to ban the substance for intra-provincial transport and importation in 1997, arguing that the additive had grave implications to public health due to its toxic components. This led the US corporation to initiate investment arbitration against the host state under the NAFTA, claiming that this ban constituted an indirect expropriation.

Much like the later AbitibiBowater case, this case ultimately did not reach an award. It went a bit further, however, as the tribunal did manage to determine its own jurisdiction, but shortly afterwards in 1998, Canada agreed to settle with the foreign investor. It agreed to pay the corporation compensation for its damages (USD 13 million) and also pay for its fees. But even more importantly, it agreed to accept MMT as a safe substance and reverse its ban.

The relevance of this case is that it served as an enduring potential example of regulatory chill, in the form of direct chill in particular. While the foreign investor did not succeed in threatening Canada into reversing its ban at first, it did ultimately manage to accomplish this. And even more noteworthy is that not only was the original ban reversed, Canada had to later rely on voluntary restrictions by local industries to lessen the presence of MMT in gasoline. ${ }^{44}$ As 
previously noted, this underscores the potential for investment arbitration to shape governmental policy on a lengthy timescale.

The next two cases are to be examined in tandem, as they both concern the same claimant: Philip Morris. Not too far apart in time, this foreign investor attempted to sue two different countries for healthcare regulations concerning tobacco. In the first, Philip Morris v. Australia, ${ }^{45}$ it attempted to use investment arbitration to prevent Australia from implementing these aforementioned measures, and also potentially to influence countries considering similar measures at the time (e.g. New Zealand). ${ }^{46}$ However, the arbitration tribunal ruled this attempt inadmissible, as the foreign investor used a quick corporate restructuring, in order to be able to sue Australia under the Australia-Hong Kong BIT. Nevertheless, Philip Morris managed to achieve its objective partially, as New Zealand's adoption of similar measures were delayed until Australia came out as the victor of the investment dispute. ${ }^{47}$

The corporation had considerably more luck, at least on the short term, in the second, Philip Morris v. Uruguay ${ }^{48}$ case, where it challenged Uruguay's new tobacco laws, aimed at mitigating endemic smoking among the population. Their suit was based on the Switzerland-Uruguay BIT. This arbitration went all the way to the merits' stage, and ultimately closed with Uruguay's victory. Due to the favorable readings given by the investment arbitrators in the case, this could be considered a strong counterexample against the other cases presented supra. However, it should be noted, that Uruguay had to rely on a charitable fund to finance its legal fees, ${ }^{49}$ without which the case could likely have had a very different outcome. Furthermore, favorable readings by one arbitration tribunal does not imply that similar affirmations of the host state's right to regulate would arrive from other tribunals, who may choose to decide more in line with the other cases presented here.

In general, these two cases represent an ongoing trend by foreign investors attempting to use investment arbitration as a tool to affect states other than their direct targets. At the moment, it seems their efficacy in this is partial and limited at best, but it does not discount the possibility completely.

The final case to be discussed in the study is the protracted case known as Renco v. Peru. ${ }^{50}$ These are actually two cases, one dismissed and one still pending. The case revolved around the privatization of a smelter. When this privatization

Philip Morris Asia Limited v. The Commonwealth of Australia, UNCITRAL, PCA Case No. 2012-12, at www.italaw.com/cases/851.

46 Lukasz Gruszczynski, 'Australian Plain Packaging Law, International Litigations and Regulatory Chilling Effect', European Journal of Risk Regulation, Vol. 5, Issue 2, 2014, p. 245.

47 Id

48 Philip Morris Brands Sàrl, Philip Morris Products S.A. and Abal Hermanos S.A. v. Oriental Republic of Uruguay, ICSID Case No. ARB/10/7, at www.italaw.com/cases/460.

49 Sabrina Tavernise, 'Tobacco Firms' Strategy Limits Poorer Nations' Smoking Laws', New York Times, 2013, at www.nytimes.com/2013/12/13/health/tobacco-industry-tactics-limit-poorernations-smoking-laws.html.

50 The Renco Group, Inc. v. Republic of Peru [I], ICSID Case No. UNCT/13/1, at www.italaw.com/ cases/906; The Renco Group, Inc. v. Republic of Peru [II], PCA Case No. 2019-46, at www.italaw.com/cases/6179. 
occurred in 1997, the US-based Renco's subsidiary made a commitment to clean up the toxic contamination caused by the metal smelting activities. Despite several Peruvian extensions to the deadline, the corporation failed to fulfill this commitment, leading to class action lawsuits against Renco's Peruvian subsidiary in Missouri (where the corporation was incorporated), demanding compensation for the Peruvian locals whose health had been allegedly affected by the smelter. As a consequence, in 2010, Renco initiated investment arbitration against Peru, claiming that the host state violated the 'fair and equitable treatment' included in the US-Peru FTA by not providing another deadline extension to the Peruvian subsidiary, and that it should be assumed liable for the class action lawsuits pending against it.

It took six years of investment arbitration for the tribunal to determine that they have no jurisdiction over the case, because the FTA included a requirement that the foreign investor must waive domestic litigation rights to advance an investment arbitration claim, something that Renco failed to do. Nevertheless, Peru incurred a significant financial cost in the course of the case, and it was a short-lived victory: in just two years, Renco launched a new investment arbitration proceeding against Peru, based on the same facts and claims. The outcome of this case is still pending.

Renco $v$. Peru serves as an excellent example for the persistence of foreign investors and the prolonged nature of many investment disputes. It is important to note here, that from a technical perspective, the failure occurred on the foreign investor's end (failing to fulfill its contractual obligations), yet, it was able to drag its host state into an extremely lengthy series of litigations that continue to this day.

\section{Conclusions}

Based on the case-law presented in the preceding three sections, it is possible to pinpoint a few important issues.

As shown by Occidental, Copper Mesa and other cases, 'unclean hands' is not a reliable defense for host states in investment arbitration. The wrongdoings of foreign investors have only a marginal effect on how efficiently they are able to pursue their claims against the host states. Even if the foreign investor is engaging in illegal activities (Copper Mesa) or failing to fulfill a direly important obligation (Renco), the tribunal will not necessarily accept the response measures of the host state. This creates the unfortunate perception of investment arbitration (and foreign investors by extension) being 'above' domestic laws, and reinforces a perceived unfairness and injustice from the public's viewpoint.

Second, local and provincial governments seem to be particularly vulnerable to investment arbitration. As shown in Abengoa, even their own central or federal authorities may oppose them in the pursuit of the foreign investor's interests. This could lead to situations where the central government, so as to avoid a costly investment arbitration, is incentivized to silence or neutralize local or provincial governments themselves, even if they are acting out of legitimate public interest. 
Furthermore, we can also note that the line between public interest and unacceptable expropriation seems rather thin and shaky. Whenever the threat of investment arbitration rises, the host state can never be certain about its outcome. Hence, there is likely an incentive to settle (Ethyl, AbitibiBowater), which actually secures a degree of victory for the foreign investor. Furthermore, even if the host state triumphs against a seemingly frivolous claim, they still likely have to spend significant time and money protecting their decisions (Veolia).

Finally, as shown by the two Philip Morris cases, there is the threat of a knockon effect. One investment arbitration case could potentially be used by foreign investors to discourage other host states from considering similar measures. And if these efforts are successful, the chilling effect can linger for a significant period of time as shown by Ethyl, where the foreign investor's effort to prevent MMT from being banned affected Canada's legislation for decades to come.

In conclusion, it is clear that the criticisms facing investment arbitration have a basis in reality, to a certain degree. The above negative tendencies reduce public faith in the system, and might eventually lead to a backlash. Good examples of this are the anti-TTIP and anti-CETA protests, which partially focused on the fact that both of these free-trade agreements would have included investment arbitration. In CETA's case, as it was noted early on the study, it actually led to an alternate dispute settlement system being created. ${ }^{51}$

As for the future, we will likely see the debate continue unimpeded. It seems probable that the current model is not very sustainable, at least with regards to public perception, so reforms will likely occur in time. However, there are still many supporters of the current investment arbitration model, including the foreign investors, who would likely not favor radical change. 